\title{
The Role of Mentorship and Homograft Repair for Endocarditis with Complex Aortic Root Abscess
}

\author{
Stephen Spindel ${ }^{1}$, Ana Claudia Costa ${ }^{2}$, Shinobu Itagaki², Bobby Yanagawa ${ }^{3}$, Joanna \\ Chikwe $^{4}$, and Paul Stelzer ${ }^{2}$ \\ ${ }^{1}$ Ochsner Medical Center - New Orleans \\ ${ }^{2}$ Mount Sinai Medical Center \\ ${ }^{3}$ St Michael's Hospital \\ ${ }^{4}$ Cedars-Sinai Medical Center
}

April 28, 2020

\begin{abstract}
Background: Aortic root abscess surgery has significant mortality but can be performed safely by trainees supervised by senior surgeons. Methods: Between 2007 and 2017, 54 consecutive patients (mean 64 years old) with active aortic endocarditis complicated with periannular abscess underwent aortic root replacement with homograft. Twenty-eight cases (52\%) in which postgraduate year 5-8 residents or junior attending surgeons performed under senior attending supervision were compared to 26 cases the senior attending performed. Mean follow-up was 2.2 years. Results: Forty-three patients (80\%) had previous aortic valve replacement and $26(48 \%)$ were in New York Heart Association class III or IV status. Forty-two patients (78\%) had concomitant procedure including 20 (37\%) aorto-mitral curtain reconstruction and 6 (11\%) hemi aortic arch replacement under circulatory arrest. Median cross clamp time was 218 minutes. There was no operative mortality. One patient (2\%) had re-exploration for bleeding and $3(6 \%)$ had stroke. Median hospital stay was 10 days. Preoperative characteristics and short and mid-term results were all comparable between mentee cases vs senior attending cases. Survival at 6 years were $67.3 \%$ $(95 \%$ CI $38.0-85.0 \%)$ in mentee cases and $75.6 \%$ (95\% CI $47.1-90.1 \%)$ in senior attending cases (adjusted hazard ratio 1.48, 95\% CI 0.33- 6.73, $\mathrm{P}=0.61)$. During follow up, 2 patients $(3.7 \%)$ required reoperation on the aorta valve for structural valve deterioration and $1(1.8 \%)$ had recurrent endocarditis. Conclusions: Homograft aortic root replacement can be performed safely by trainees with an experienced surgeon showing favorable outcomes, midterm survival, and freedom from recurrent endocarditis.
\end{abstract}

\section{Introduction}

Infective endocarditis (IE) involving the aortic valve is associated with risk of heart failure, septic embolism and conduction block (1). About twenty percent of these patients have extension of the infection into the surrounding aortic root in the form of abscess (1). Root abscesses occur more commonly in prosthetic valve endocarditis (PVE) than native valve endocarditis (2). The definitive management of such is surgical which often carries high risk of mortality, ranging between $14 \%$ to $26 \%$ (2-4) with some reporting up to $39 \%$ mortality for PVE (5).

The principal of surgery for IE is radical debridement of all infected tissues and replacement of necessary structures. Surgery for aortic root abscess involves extensive debridement followed by root reconstruction with pericardial patch plus aortic valve replacement or root replacement, often by a cryopreserved homograft. Our strategy for aortic root abscess has been radical resection of infected material, repair of any fistulae and other cardiac defects with biological material (autologous or bovine pericardium), and homograft reconstruction of the aortic root. In this report, we review our institutional experience in surgical management 
of infective endocarditis with aortic root abscess using homograft. We also review whether this technically demanding operation can be safely passed on to the next generation of cardiac surgeons (6).

\section{Materials and Methods}

\section{Patient Data}

Clinical, operative, and outcome data were collected retrospectively for all consecutive patients with aortic root replacement for active IE with aortic root abscess between 2007 and 2017. All patients underwent surgery at a single institution (Mount Sinai Hospital, NY) by a single surgeon (PES) or by integrated residents/conventional fellows (postgraduate year 5 to 8 ) or junior attending surgeons within 2 years of their graduation from the training program under the supervision of the senior surgeon. This study was approved by the Program for Protection of Human Subjects at the Icahn School of Medicine at Mount Sinai. The approval included a waiver of informed consent.

\section{Clinical Outcomes and Definitions}

We reviewed all relevant clinical outcomes including all-cause mortality, aortic valve reoperation, recurrent endocarditis, and New York Heart Association (NYHA) functional class. Operative mortality was defined as any death within 30 days, or at any time during the same hospital stay. Postoperative morbidity was defined as major adverse cardiac and cerebral events (stroke or myocardial infarction), respiratory failure (prolonged mechanical ventilation $>48$ hours, tracheostomy, or need for reintubation), acute renal failure requiring renal replacement therapy, and requirement of new permanent pacemaker. Long-term clinical outcome data including NYHA functional class, recurrence and reoperations were obtained for all patients by personal contacts via phone interviews and office visits. Residents/fellows and junior attending surgeons were considered as a primary surgeon only when they performed all or most of the key portions of the operation. Mean follow-up was 2.2 years (range: 0.1 to 9.1 years).

\section{Operative Management}

All cases were performed with median sternotomy. Myocardial protection was moderate systemic hypothermia with primarily retrograde cold blood cardioplegia given every twenty minutes.

Infection extension over the left atrial roof commonly occurred and was debrided completely including the aorto-mitral curtain if necessary. Penetration into the ventricular septum was aggressively debrided down to healthy looking muscle. Rebuilding the heart depended on how much was removed. With mitral valve involvement, valve repair or replacement was performed before proceeding to the root reconstruction. The left atrial roof and curtain was rebuilt with autologous or bovine pericardial tissue.

Sizing of the aortic homograft was performed on the basis of echo measurement of the aortic annulus and directly. If all sizes were available, the largest possible size was chosen.

Interrupted 4-0 polypropylene sutures were placed around the debrided aortic root and curtain. Incorporating a $5 \mathrm{~mm}$ wide strip of bovine pericardium on the outside of the root added strength and hemostasis so each stitch was passed through the pericardium as it was placed. The sutures were placed through the homograft from the inside out. The homograft was oriented anatomically with donor mitral matching recipient aortomitral curtain and the sutures were tied.

Coronary buttons were reimplanted into the sites of the homograft coronary stumps with continuous 5-0 polypropylene. The distal end of the homograft was trimmed and sewn to the native aorta with continuous 4-0 polypropylene.

In the majority of the patients, the hemostasis was expected to be challenging due to the combination of the preoperative deconditioning due to infection, friable tissue, and technically demanding and lengthy operation. Therefore, a Cabrol patch with Cooley fistula was often applied preemptively. This was performed with a large patch of bovine pericardium sewn to the homograft superiorly, right ventricle outflow tract and right atrium inferiorly, the main pulmonary trunk medially, and superior vena cava laterally, creating a closed 
space around the root. A small right atriotomy was made before closing this closed space, creating a perigraft to right atrium shunt.

Postoperative conduction disorder was highly expected due to radical debridement of infective tissue, so permanent epicardial pacing electrodes were often preemptively placed.

\section{Results}

\section{Patient Characteristics}

Between 2007 and 2017, 54 patients underwent aortic root replacement with coronary reimplantation using cryopreserved valved aortic homograft. Baseline patient characteristics are listed in Table $\mathbf{1}$. There was no significant difference in baseline characteristics between resident/junior attending cases and senior attending cases. Mean age was 63.7 years (range $30-84$ years) and $11 \%$ were female. Two patients (3.7\%) were in extremis and taken to the operating room emergently. Nine (16.7\%) were in NYHA III and 17 (31.5\%) were in NYHA IV prior to the operation. Five patients $(9.3 \%)$ had new atrioventricular nodal dysfunction including complete heart block. The most common infective agents were Streptococcus viridans $(24.1 \%)$, Staphylococcus aureus (22.2\%), Staphylococcus epidermidis (13.0\%), and Enterococcus species (13.0\%).

\section{Perioperative Details}

Intraoperative variables are shown in Table 2 . All 54 patients underwent replacement of the aortic root with coronary reimplantation using cryopreserved homograft. Forty-two patients $(77.8 \%)$ had concomitant surgical procedures including aorto-mitral curtain reconstruction in $20(37.0 \%)$, mitral valve repair in 13 (24.1\%), bioprosthetic mitral valve replacement in 10 (18.5\%), tricuspid valve repair in 9 (16.7\%), and hemi aortic arch replacement under circulatory arrest in 6 (11.1\%). Ten patients (18.5\%) had radical debridement and patch repair or primary closure of aorto-atrial fistulae and/or acquired atrial or ventricular septal defects due to extensive abscess formation with tissue destruction. Of these, three had aorto-atrial fistulae, five had atrial septal defects, and two had ventricular septal defects. Nineteen patients (35.2\%) with reoperative surgery required Cabrol patch with Cooley fistula due to excessive aortic root hemorrhage. Senior attending cases tended to have more aorto-mitral curtain reconstruction $(25.0 \%$ vs $50.0 \%, \mathrm{P}=0.057)$ and also required Cabrol patch ( $17.9 \%$ vs $53.9 \%, \mathrm{P}=0.006)$. The median cross clamp time was comparable (213 vs 227 minutes, $\mathrm{P}=0.08)$, but the median cardiopulmonary bypass time was longer in the senior attending cases (280 vs 342 minutes, $\mathrm{P}=0.05)$.

\section{Post-Operative Outcomes}

Postoperative outcomes are summarized in Table 3 . There were no in-hospital deaths and 3 strokes (5.6\%). Of the 10 patients (18.5\%) who experienced respiratory failure, 5 had prolonged intubation ( $>48$ hours) and 5 had tracheostomy. Six patients $(11.1 \%)$ required renal replacement therapy and 1 patient underwent re-exploration for bleeding. The median hospital length of stay was 10 days.

Overall actuarial survival at 1 year and 6 years was $81.7 \%$ (95\% CI, $63.7-91.4 \%)$ and $70.4 \%$ (95\% CI, 50.1 $-83.6 \%$ ), respectively. Mid-term survival was similar between the groups at $67.3 \%$ (95\% CI $38.0-85.0 \%)$ in resident/junior attending cases and $75.6 \%(95 \%$ CI $47.1-90.1 \%)$ in senior attending cases (adjusted hazard ratio $1.48,95 \%$ CI $0.33-6.73, \mathrm{P}=0.61$ ) (Figure 1 ). Reinfection occurred in 1 patient within 1 year of surgery and was associated with recurrent intravenous drug use. There were 2 reoperations for homograft structural valve deterioration: 1 in year 3 and 1 in year 7 . One hundred percent of patients alive were in NYHA I or II at the last follow-up.

\section{Statistical Analysis}

Continuous variables were expressed as means and standard deviations if normally distributed or median and range for skewed distributions. Categorical variables were expressed as frequencies and proportions. Differences between groups were evaluated using the $\chi^{2}$ test or Fisher's exact test for categorical variables as appropriate and independent samples Student t test or the Mann-Whitney U test for continuous variables depending on the distribution. Survival curves of the primary end point of all-cause mortality were 
constructed with Kaplan-Meier methodology. Due to limited number of events, the propensity score adjusted proportional hazards model was fit with only resident/junior attending vs senior attending status and propensity scores incorporated as covariates to evaluate the adjusted risk. Propensity scores were calculated using logistic regression for resident/junior attending cases adjusting for preoperative comorbidities including age, gender, ejection fraction, diabetes, dialysis dependent, cerebral vascular accident, chronic obstructive lung disease, preoperative intubation, peripheral vascular disease, NYHA classification III or IV, prosthetic aortic valve endocarditis, causative organism, as well as operative details such as aorto-mitral curtain reconstruction, fistula repair, pulmonary homograft use, ascending aorta replacement, mitral valve repair, mitral valve replacement, tricuspid valve repair, coronary artery bypass grafting (the $\mathrm{C}$-statistic 0.81 ). Proportional hazards assumption was evaluated and valid. We also conducted the sensitivity analysis categorizing the groups between trainee vs attending cases by adding junior attending cases to senior attending cases and the finds remained the same. All tests were two-tailed and an alpha level of 0.05 was considered statistically significant. All statistical analyses were performed using SAS version 9.4 (SAS Institute, Cary, North Carolina).

\section{Conclusions}

Infective endocarditis is associated with high morbidity and mortality in spite of efforts for earlier diagnosis and advances in antibiotic treatment $(3,7-10)$. The use of homografts has been promoted for the treatment of IE as some evidence suggests a lower risk of recurrent infection especially in cases of PVE (8-13). Analysis of our ten-year experience with the use of homografts for aortic root reconstruction in complex endocarditis showed that this operation may be performed safely, with low associated operative mortality and morbidity and with excellent mid-term freedom from recurrence and reoperation. Also, our data suggests that despite its complexity, homograft aortic root replacement can be safely taught to residents and early staff surgeons in cardiothoracic training programs, with a few key provisos.

Arguments against the use of homografts include lack of prompt availability, a technically more challenging operation, specific surgical expertise, and increased potential for perioperative morbidity and mortality (14). Furthermore, there are concerns regarding its long-term durability and difficult reoperation scenarios due to extreme late conduit calcification $(4,15,16)$. On the other hand, homografts have superior hemodynamics, a low incidence of thromboembolic complications and do not require permanent anticoagulation. Endocarditis with advanced root involvement may present with challenging anatomical lesions, such as fistulae, extensive destruction of the fibrous skeleton, and aorto-ventricular discontinuity. In such cases, homografts may greatly facilitate surgical reconstruction of the left ventricular outflow tract due to superior tissue pliability and apposition versus other rigid synthetic materials, excellent hemostatic properties, and the presence of the donor anterior mitral leaflet, which may be used during repair (17). Our series readdresses some of these aspects.

Early mortality in endocarditis with root abscesses have been reported in the range of 13-25\% $(3,7-10,14,17)$. This is likely secondary not only to the severity of the condition but also to the extensive surgical procedures that are necessary $(13,18)$. In our series of 54 consecutive patients operated for root abscess, we had no early deaths, which we attribute to a combination of early intervention, aggressive debridement, meticulous attention to myocardial protection and hemostasis, and impeccable intensive care unit management. The survival estimate at 1 year and 7 years was $82 \%$ and $70 \%$, respectively. Notably, $60 \%$ of the late deaths occurred within the first year after the operation. For the same time period, rate of reinfection and need for reoperation were $1.8 \%$ and $5.6 \%$ respectively. Our reinfection rate is low when compared to other similar series $(7,8,10)$. We again attribute that to our policy of aggressive debridement, early surgical intervention and the choice of homograft use. In the literature, there is higher incidence of reinfection within the first year after the operation and that this is commonly associated with same organism infection or culture negative infections $(7,8,11)$. In our series, the only reinfection case was also caused by the same organism present at the initial operation.

As with any type of biological heart valve substitute, structural valve degeneration is an expected late complication. At late follow-up 2 patients $(5.6 \%)$ patients required a reoperation on the aortic position. One 
was due to stenosis and the second was due to late leaflet perforation. For those who required reoperations, the degree of calcification noted in the aortic homograft conduit did not impose additional difficulty and did not translate into additional mortality. We believe that with proper planning and careful surgical technique, reoperations can be carried out safely with results comparable to reoperation from other procedures. Moreover, the more recent introduction of decellularization techniques have been very promising in decreasing the degree of calcification of implanted homografts (19).

There are a few important provisos when interpreting our comparable outcomes by the mentees. Firstly, the outcomes must be viewed in context of the overall experience of the senior surgeon who performs 50-100 aortic root operations annually with operative mortality for cumulative experience of more than 600 Ross operations reported at less than $1 \%(20)$. It is unlikely that our experience could be easily replicated by a surgeon performing low volumes of aortic root surgery. Secondly, the responsible surgeon dictates whether aortic root surgery may be taught to residents/early staff surgeons without compromising patient outcomes. The surgeon must not only be able to perform aortic root surgery to a high standard but also be practiced enough to do this by assisting a more junior surgeon from the left-hand side of the table in such way that the flow of surgery remains efficient. Lastly, the teaching surgeon must precisely match case complexity to mentee's competencies. While some important variables that might dictate whether the case should be performed by the attending surgeon such as requirement of radical aorto-mitral curtain reconstruction were included in our analysis, some other factors are not accounted for such as extreme frailty, difficult exposure, or tissue friability that are equally important in the decision making. Similarly, our broad categorization of mentees based on the postgraduate year may provide little insight into the nuances of skills assessment required to be capable of safely performing the complex root surgery.

The main limitations of this study include the absence of a control group, precluding the more accurate assessment of comparative effectiveness of the homograft repair against other alternatives such as a prosthetic valved conduit or other surgeons. Additionally, negative findings in the relatively small sample size and limited follow-up need to be interpreted in context.

In conclusion, our study suggests that the use of homograft for aortic root reconstruction in complex aortic root endocarditis provides excellent early and mid-term outcomes and can be taught to residents or early staff surgeons by a surgeon with sufficient depth of both surgical and teaching expertise.

\section{Author Contributions}

All authors have contributed significantly to the production of this manuscript. Spindel contributed to concept, design, data acquisition, drafting article, and revision of article. Costa contributed to data acquisition, drafting article, and revision of article. Itagaki contributed to drafting article, data analysis, data interpretation, statistics, and revision of article. Yanagawa contributed to drafting article and revision of article. Chikwe contributed to concept, design, and revision of article. Stelzer contributed to concept, design, drafting article, revision of article, and approval of article.

\section{Disclosure}

This manuscript has not been published elsewhere. Dr. Joanna Chikwe received speaker honoraria from Edwards Lifesciences. No conflicts of interest for the other authors.

\section{References}

1. Anguera I, Miro JM, Cabell CH, Abrutyn E, Fowler VG, Jr., Hoen B, et al. Clinical characteristics and outcome of aortic endocarditis with periannular abscess in the International Collaboration on Endocarditis Merged Database. Am J Cardiol. 2005;96(7):976-81.

2. Musci M, Weng Y, Hubler M, Amiri A, Pasic M, Kosky S, et al. Homograft aortic root replacement in native or prosthetic active infective endocarditis: twenty-year single-center experience. J Thorac Cardiovasc Surg. 2010;139(3):665-73.

3. Leontyev S, Davierwala PM, Krogh G, Feder S, Oberbach A, Bakhtiary F, et al. Early and late outcomes of complex aortic root surgery in patients with aortic root abscesses. Eur J Cardiothorac 
Surg. 2016;49(2):447-54; discussion 54-5.

4. Solari S, Mastrobuoni S, De Kerchove L, Navarra E, Astarci P, Noirhomme P, et al. Over 20 years experience with aortic homograft in aortic valve replacement during acute infective endocarditis. Eur J Cardiothorac Surg. 2016;50(6):1158-64.

5. Anguera I, Miro JM, San Roman JA, de Alarcon A, Anguita M, Almirante B, et al. Periannular complications in infective endocarditis involving prosthetic aortic valves. Am J Cardiol. 2006;98(9):1261-8.6.

6. Stephens EH, Goldstone AB, Fiedler AG, Vardas PN, Pattakos G, Lou X, et al. Appraisal of mentorship in cardiothoracic surgery training. J Thorac Cardiovasc Surg. 2018; 5223(18): 31791-4.

7. Leontyev S, Borger MA, Modi P, Lehmann S, Seeburger J, Doenst T, et al. Surgical management of aortic root abscess: a 13-year experience in 172 patients with $100 \%$ follow-up. J Thorac Cardiovasc Surg. 2012;143(2):332-7.

8. David TE, Regesta T, Gavra G, Armstrong S, Maganti MD. Surgical treatment of paravalvular abscess: long-term results. Eur J Cardiothorac Surg. 2007;31(1):43-8.

9. Sabik JF, Lytle BW, Blackstone EH, Marullo AG, Pettersson GB, Cosgrove DM. Aortic root replacement with cryopreserved allograft for prosthetic valve endocarditis. Ann Thorac Surg. 2002;74(3):6509; discussion 9.

10. Yankah AC, Pasic M, Klose H, Siniawski H, Weng Y, Hetzer R. Homograft reconstruction of the aortic root for endocarditis with periannular abscess: a 17-year study. Eur J Cardiothorac Surg. 2005;28(1):69-75.

11. McGiffin DC, Galbraith AJ, McLachlan GJ, Stower RE, Wong ML, Stafford EG, et al. Aortic valve infection. Risk factors for death and recurrent endocarditis after aortic valve replacement. J Thorac Cardiovasc Surg. 1992;104(2):511-20.

12. McGiffin DC, Kirklin JK. The impact of aortic valve homografts on the treatment of aortic prosthetic valve endocarditis. Semin Thorac Cardiovasc Surg. 1995;7(1):25-31.

13. Langley SM, Alexiou C, Stafford HM, Dalrymple-Hay MJ, Haw MP, Livesey SA, et al. Aortic valve replacement for endocarditis: determinants of early and late outcome. J Heart Valve Dis. 2000;9(5):697704.

14. Niwaya K, Knott-Craig CJ, Santangelo K, Lane MM, Chandrasekaran K, Elkins RC. Advantage of autograft and homograft valve replacement for complex aortic valve endocarditis. Ann Thorac Surg. 1999;67(6):1603-8.

15. Arabkhani B, Bekkers JA, Andrinopoulou ER, Roos-Hesselink JW, Takkenberg JJ, Bogers AJ. Allografts in aortic position: Insights from a 27-year, single-center prospective study. J Thorac Cardiovasc Surg. 2016;152(6):1572-9 e3.

16. O'Brien MF, Harrocks S, Stafford EG, Gardner MA, Pohlner PG, Tesar PJ, et al. The homograft aortic valve: a 29-year, 99.3\% follow up of 1,022 valve replacements. J Heart Valve Dis. 2001;10(3):334-44; discussion 5 .

17. Knosalla C, Weng Y, Yankah AC, Siniawski H, Hofmeister J, Hammerschmidt R, et al. Surgical treatment of active infective aortic valve endocarditis with associated periannular abscess-11 year results. Eur Heart J. 2000;21(6):490-7.

18. Nguyen DT, Delahaye F, Obadia JF, Duval X, Selton-Suty C, Carteaux JP, et al. Aortic valve replacement for active infective endocarditis: 5-year survival comparison of bioprostheses, homografts and mechanical prostheses. Eur J Cardiothorac Surg. 2010;37(5):1025-32.

19. da Costa FD, Costa AC, Prestes R, Domanski AC, Balbi EM, Ferreira AD, et al. The early and midterm function of decellularized aortic valve allografts. Ann Thorac Surg. 2010;90(6):1854-60.

20. Stelzer P, Itagaki S, Varghese R, Chikwe J. Operative mortality and morbidity after the Ross procedure: a 26- year learning curve. J Heart Valve Dis. 2013 Nov;22(6):767-75.

\section{Tables}

Table 1: Clinical characteristics of patients undergoing homograft aortic root replacement for aortic root abscess 


\begin{tabular}{|c|c|c|c|c|}
\hline Variable & Total cases $(\mathrm{n}=54)$ & $\begin{array}{l}\text { Resident/Junior } \\
\text { attending cases } \\
(\mathrm{n}=28)\end{array}$ & $\begin{array}{l}\text { Senior attending } \\
\text { cases }(\mathrm{n}=26)\end{array}$ & $\mathrm{P}$ \\
\hline Age, y & $64 \pm 14$ & $65 \pm 14$ & $62 \pm 13$ & 0.49 \\
\hline Female & $6(11.1)$ & $4(14.3)$ & $2(7.7)$ & 0.67 \\
\hline $\begin{array}{l}\text { Ejection Fraction, } \\
\%\end{array}$ & $54 \pm 10$ & $54 \pm 10$ & $53 \pm 11$ & 0.73 \\
\hline $\begin{array}{l}\text { Previous Cerebral } \\
\text { Vascular Accident }\end{array}$ & $22(40.7)$ & $10(35.7)$ & $12(46.2)$ & 0.44 \\
\hline Intubated & $8(14.8)$ & $5(17.9)$ & $3(11.5)$ & 0.71 \\
\hline $\begin{array}{l}\text { Chronic } \\
\text { Obstructive } \\
\text { Pulmonary } \\
\text { Disease }\end{array}$ & $6(11.1)$ & $4(14.3)$ & $2(7.7)$ & 0.67 \\
\hline $\begin{array}{l}\text { Renal } \\
\text { Insufficiency }\end{array}$ & $18(33.3)$ & $11(39.3)$ & $7(26.9)$ & 0.34 \\
\hline $\begin{array}{l}\text { Dialysis } \\
\text { Dependent }\end{array}$ & $5(9.3)$ & $3(10.7)$ & $2(7.7)$ & 1.0 \\
\hline Diabetes Mellitus & $16(29.6)$ & $10(35.7)$ & $6(23.1)$ & 0.31 \\
\hline $\begin{array}{l}\text { Peripheral } \\
\text { Vascular Disease }\end{array}$ & $8(14.8)$ & $5(17.9)$ & $3(11.5)$ & 0.71 \\
\hline $\begin{array}{l}\text { Previous Aortic } \\
\text { Valve Surgery }\end{array}$ & $43(79.6)$ & $21(75.0)$ & $22(84.6)$ & 0.38 \\
\hline $\begin{array}{l}\text { NYHA class } \\
\text { III-IV } \\
\text { Infective } \\
\text { Organism }\end{array}$ & $26(48.1)$ & $13(46.4)$ & $13(50.0)$ & 0.79 \\
\hline Strep. viridans & $13(24.1)$ & $6(21.4)$ & $7(26.9)$ & 0.64 \\
\hline Staph. aureus & $12(22.2)$ & $8(28.6)$ & $4(15.4)$ & 0.24 \\
\hline $\begin{array}{l}\text { Staph. } \\
\text { epidermidis }\end{array}$ & $7(13.0)$ & $3(10.7)$ & $4(15.4)$ & 0.70 \\
\hline $\begin{array}{l}\text { Enterococcus } \\
\text { species }\end{array}$ & $7(13.0)$ & $4(14.3)$ & $3(11.5)$ & 1.0 \\
\hline Candida species & $3(5.6)$ & $2(7.1)$ & $1(3.9)$ & 1.0 \\
\hline Others & $7(13.0)$ & $3(10.7)$ & $4(15.4)$ & 0.70 \\
\hline Culture negative & $5(9.3)$ & $2(7.1)$ & $3(11.5)$ & 0.66 \\
\hline
\end{tabular}

Values are $\mathrm{n}(\%)$, or mean \pm standard deviation, unless otherwise indicated

Abbreviations: NYHA, New York Heart Association

Table 2: Operative details of patients undergoing homograft aortic root replacement for aortic root abscess

\begin{tabular}{lllll}
\hline & & $\begin{array}{l}\text { Resident/Junior } \\
\text { attending cases } \\
(\mathrm{n}=28)\end{array}$ & $\begin{array}{l}\text { Senior attending } \\
\text { cases }(\mathrm{n}=26)\end{array}$ & $\mathrm{P}$ \\
\hline $\begin{array}{l}\text { Variable } \\
\text { poncomitant }\end{array}$ & $42(77.8)$ & $21(75.0)$ & $21(80.8)$ & 0.61 \\
$\begin{array}{l}\text { Hemiarch } \\
\text { replacement }\end{array}$ & $6(11.1)$ & $3(10.7)$ & $3(11.5)$ & 1.0
\end{tabular}




\begin{tabular}{|c|c|c|c|c|}
\hline Variable & Total cases $(\mathrm{n}=54)$ & $\begin{array}{l}\text { Resident/Junior } \\
\text { attending cases } \\
(\mathrm{n}=28)\end{array}$ & $\begin{array}{l}\text { Senior attending } \\
\text { cases }(\mathrm{n}=26)\end{array}$ & $\mathrm{P}$ \\
\hline $\begin{array}{l}\text { Aorto-Mitral } \\
\text { Curtain } \\
\text { Reconstruction }\end{array}$ & $20(37.0)$ & $7(25.0)$ & $13(50.0)$ & 0.057 \\
\hline $\begin{array}{l}\text { Mitral Valve } \\
\text { Repair }\end{array}$ & $13(24.1)$ & $7(25.0)$ & $6(23.0)$ & 0.87 \\
\hline $\begin{array}{l}\text { Mitral Valve } \\
\text { Replacement }\end{array}$ & $10(18.5)$ & $3(10.7)$ & $7(26.9)$ & 0.17 \\
\hline $\begin{array}{l}\text { Tricuspid Valve } \\
\text { Repair }\end{array}$ & $9(16.7)$ & $4(14.3)$ & $5(19.2)$ & 0.72 \\
\hline CABG & $4(7.4)$ & $3(10.7)$ & $1(3.9)$ & 0.61 \\
\hline $\begin{array}{l}\text { Acquired ASD, } \\
\text { VSD, and/or } \\
\text { Fistula Repair }\end{array}$ & $10(18.5)$ & $4(14.3)$ & $6(23.1)$ & 0.49 \\
\hline $\begin{array}{l}\text { Pulmonary } \\
\text { Homograft }\end{array}$ & $1(1.9)$ & $0(0)$ & $1(3.9)$ & 0.48 \\
\hline $\begin{array}{l}\text { Epicardial Lead } \\
\text { Placement }\end{array}$ & $5(9.3)$ & $2(7.1)$ & $3(11.5)$ & 0.66 \\
\hline $\begin{array}{l}\text { Cabrol Patch } \\
\text { with Cooley } \\
\text { Fistula }\end{array}$ & $19(35.2)$ & $5(17.9)$ & $14(53.9)$ & 0.0057 \\
\hline Reoperation & $43(79.6)$ & $21(75.0)$ & $22(84.6)$ & 0.38 \\
\hline $\begin{array}{l}\text { Cardiopulmonary } \\
\text { Bypass Time, min } \\
\text { [IQR] }\end{array}$ & $294[245-364]$ & $280[238-332]$ & $342[253-417]$ & 0.048 \\
\hline $\begin{array}{l}\text { Cross Clamp } \\
\text { Time. Min [IQR] }\end{array}$ & 218 [193-272] & 213 [183-244] & 227 [ 205-304] & 0.082 \\
\hline
\end{tabular}

Values are $\mathrm{n}(\%)$, or mean \pm standard deviation, unless otherwise indicated

Abbreviations: ASD, atrial septal defect; CABG, coronary artery bypass graft; IQR, interquartile range; VSD, ventricular septal defect

Table 3: Postoperative outcomes of patients undergoing homograft aortic root replacement for aortic root abscess

\begin{tabular}{|c|c|c|c|c|}
\hline & Total cases $(\mathrm{n}=54)$ & $\begin{array}{l}\text { Resident/Junior } \\
\text { attending cases } \\
(\mathrm{n}=28)\end{array}$ & $\begin{array}{l}\text { Senior attending } \\
\text { cases }(\mathrm{n}=26)\end{array}$ & $\mathrm{P}$ \\
\hline $\begin{array}{l}\text { Hospital Stay, } \\
\text { days [IQR] }\end{array}$ & $10[8-17]$ & $9[7-14]$ & $11[9-18]$ & 0.24 \\
\hline $\begin{array}{l}\text { Operative } \\
\text { Mortality } \\
\text { Complications }\end{array}$ & $0(0)$ & $0(0)$ & $0(0)$ & \\
\hline $\begin{array}{l}\text { Cerebral Vascular } \\
\text { Accident }\end{array}$ & $3(5.6)$ & $1(3.6)$ & $2(7.7)$ & 0.60 \\
\hline $\begin{array}{l}\text { Respiratory } \\
\text { Failure }\end{array}$ & $10(18.5)$ & $3(10.7)$ & $7(26.9)$ & 0.17 \\
\hline
\end{tabular}




\begin{tabular}{lllll}
\hline & Total cases $(\mathrm{n}=54)$ & $\begin{array}{l}\text { Resident/Junior } \\
\text { attending cases } \\
(\mathrm{n}=28)\end{array}$ & $\begin{array}{l}\text { Senior attending } \\
\text { cases }(\mathrm{n}=26)\end{array}$ & $\mathrm{P}$ \\
\hline $\begin{array}{l}\text { Renal } \\
\text { Replacement }\end{array}$ & $6(11.1)$ & $2(7.1)$ & $4(15.4)$ & 0.41 \\
$\begin{array}{l}\text { Therapy } \\
\text { Permanent }\end{array}$ & $16(29.6)$ & $4(14.3)$ & $12(46.2)$ & 0.01 \\
$\begin{array}{l}\text { Pacemaker } \\
\begin{array}{l}\text { Insertion } \\
\text { Re-exploration for } \\
\text { Bleeding }\end{array}\end{array}$ & $1(1.9)$ & $0(0)$ & $1(3.9)$ & 0.48 \\
\hline
\end{tabular}

Values are $\mathrm{n}(\%)$, or mean \pm standard deviation, unless otherwise indicated

Abbreviations: IQR, interquartile range

\section{Figure Legends}

Figure 1: Survival Estimate of patients after homograft root replacement for aortic endocarditis, stratified by resident/fellow/junior attending cases (mentee) vs senior attending cases (mentor)

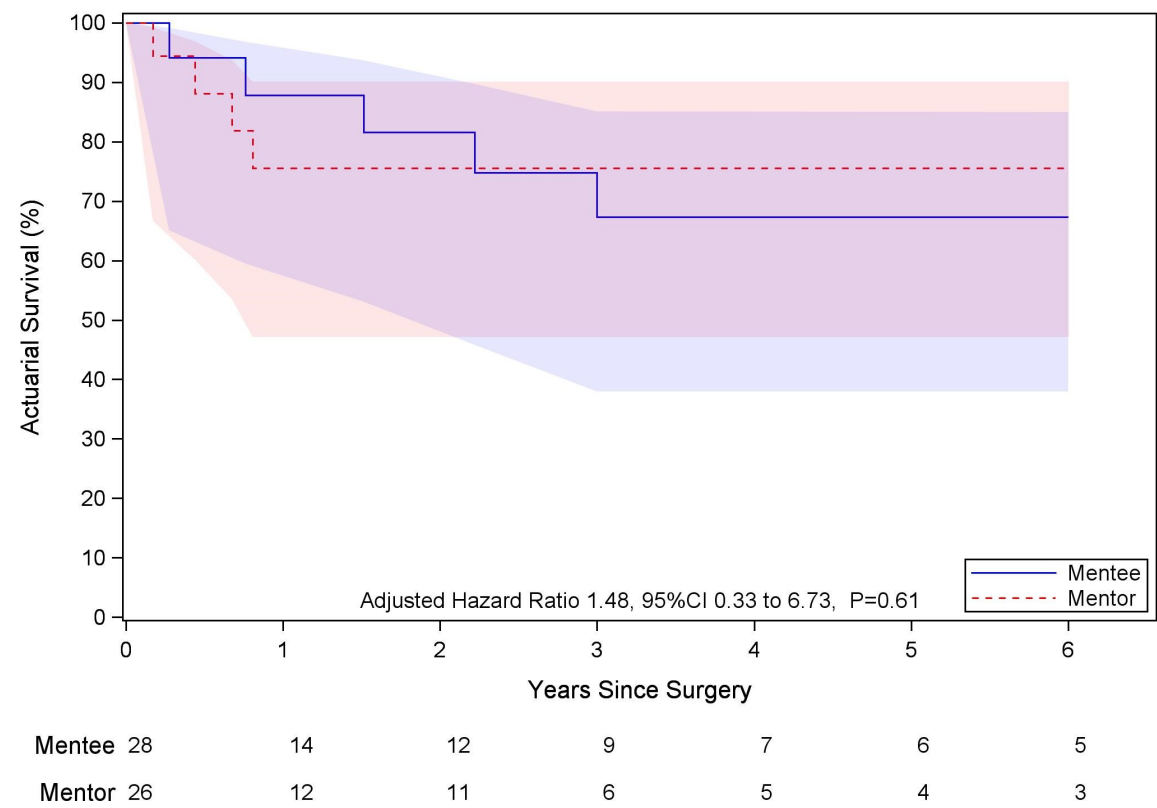

